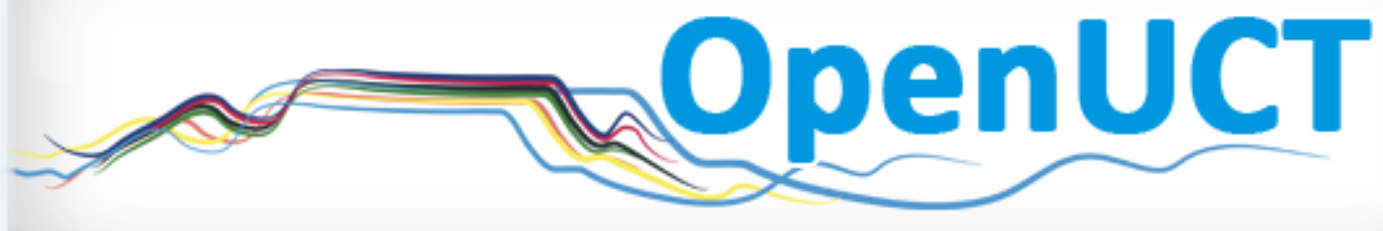

This is the post-print of Paxton, M. 2007. Students' interim literacies as a dynamic resource for teaching and transformation. Southern African Linguistics and Applied Language Studies. 25(1): 45-55. DOI: 10.2989/16073610709486445.

It is made available according to the terms of agreement between the author and the journal, and in accordance with UCT's open access policy available:

http://www.openuct.uct.ac.za/sites/default/files/UCTOpenAccessPolicy.pdf, for the purposes of research, teaching and private study. 


\title{
Students' interim literacies as a dynamic resource for teaching and transformation
}

\author{
Moragh Paxton \\ Centre for Higher Education Development, University of Cape Town, Private Bag, \\ Rondebosch 7700, South Africa \\ e-mail: mpaxton@ched.uct.ac.za
}

\begin{abstract}
This article explores the notion of 'interim literacies' by drawing on data from a research project which used linguistic and intertextual analysis of first year student writing in economics to investigate the intersection of academic discourse and student voice. This research has provided a rich set of data to illustrate the ways in which first year student texts are built from a range of past and present discourses, discourse strategies and genres. Students make meaning by reworking past discourses, appropriating and adapting new discourses to make them their own. The article goes on to develop the notion of interim literacies by refining criteria for deciding what interim literacies are and what they are not. The notion of interim literacies is used to move away from a 'deficit' view of English second language writers in the university and it is argued that an analysis and understanding of interim literacies can contribute to teaching and to transformation. The article concludes by providing evidence of the ways in which this research project has impacted on teaching and curricula in the university course where the project was undertaken.
\end{abstract}

\section{Introduction}

This article is concerned with literacy, a term which has absorbed a range of different meanings and which many theorists consider to be a contested term. A range of theory and research that focuses on literacy and literacy practices within social practice, using mainly ethnographic methods, has developed as a sub-discipline known as the New Literacy Studies (NLS). Through the New Literacy Studies, literacy has become the focus of interest for disciplines, such as anthropology, sociology, psychology and education.

Two models identified by Street (1995), namely an autonomous model and an ideological model, have become influential in theorising literacy in the NLS. Street described the notion that literacy is a universal technical skill, as the 'autonomous' model of literacy. He contrasted this notion with the 'ideological' model, which argues that not only does literacy vary across social contexts but that its uses and meanings are always embedded in relations of power. If literacy is treated as autonomous, then the social features tend to be naturalised and the history and ideology behind school literacy is disguised.

This article sets out to explore the notion of 'interim literacies' ${ }_{1}$, a term which was introduced and developed in a research project undertaken at the University of Cape Town (Paxton, 2004) which used linguistic and intertextual analysis of first year student writing to investigate the intersection of the academic discourses and student voice. The research project will be described and the notion of interim literacies will be further developed by grounding it empirically in data from the project in order to clarify what interim literacies are. The discussion will identify a set of features typical of interim literacies and then consider whether all language and literacy practices at a foundational level can be considered as 'interim'. As with all new constructs it also seems important to raise some critical questions relating to the term interim literacies. The article will conclude by considering why the interim literacy stage is important for teaching and for transformation. 


\section{Theoretical and methodological framework}

Gee (1996) points out that any socially useful definition of literacy should be framed in terms of notions of primary and secondary discourses, but before discussing this, it is important to distinguish the concept of literacies from that of discourses. Kress (1985: 7) offers one of the clearest descriptions of discourses. He states

Discourses are systematically-organised sets of statements which give expression to the meanings and values of an institution. Beyond that, they define, describe and delimit what it is possible to say and not possible to say (and by extension what it is possible to do or not to do) with respect to the area of concern of that institution.

Gee (1996) identifies primary discourses as those which people acquire early in life in the family home, whereas secondary discourses are those acquired from social institutions outside the home, for example, the church, the school and the office. Academic discourse is thus often referred to as a secondary discourse. Primary discourses form the base for acquisition of secondary discourses and they shape the form that acquisition and learning will take. Following from this, Gee defines literacy as 'mastery or fluent control ... over a secondary discourse' (1996: 143). However, very few students at first year university level could be said to have mastery over the new discourses they are acquiring and therefore I have used the construct of 'interim literacies' to describe first year student writing practices and to account for the heteroglossic nature of their texts.

The study investigates the acquisition of the new academic discourse by drawing on Bakhtin's (1981) concept of intertextuality to consider the discourses, discourse models and literacy and learning practices that students draw on as they write their essays. The term 'intertextuality' is used very broadly to refer to all ways in which a specific text relates to other texts and voices. I use the term 'voices' in the Bakhtinian sense of a discoursal repertoire which is inevitably social and ideological. 'Voices' are a set of discourses that the writer brings to the act of writing; they are part of his/her social and historical formation and they weave their way intertextually through the writing. In the context in which I am using the term, interim literacies reflect a transition process from school and home to academic literacy.

The concept of interim literacies seems useful in a context of increasing cultural and linguistic diversity where students draw on a range of other discourses as they learn to make meaning in a new discourse. It also seems appropriate in a context of changing socio-political and policy contexts globally, but particularly in South Africa. It allowed me to understand language and meaning-making as a dynamic resource, constantly being adapted and transformed by its users. Clearer insights into interim literacies prompted me to question the dominant role of Western essayist literacy and traditional educational methodologies in our academic institutions.

Connected to my notion of what is interim is Kress's new theory of meaning $(2000,2002,2004)$, the idea that all meaning-making is dynamic. Kress (2000: 154) argues that current theories of semiosis centred around language as they are, describe the 'use of an existing and stable system' of conventions and rules, but this is not a helpful theory for the era of multimedia and multiliteracies. He argues that the resources of representation are always in a process of change. We cannot see individuals as mere users of a system; we need to see that they are transformers of the semiotic system, that changes in use and form take place constantly and that remaking reflects individual interests on the one hand and social history and cultural issues on the other. His notion of 'interest' ensures that the agency of the sign-maker is recognised but he emphasises that signmakers are always working within fields of power with historically shaped resources.

In the study I analysed the first and last essays in a first-year economics course exploring the shifts and changes that take place over the first academic year. I was both teacher and researcher in that I teach one of the groups in the Language and Communications course which runs as an adjunct module to the Economics course. Eight students from different socio-economic backgrounds volunteered as research subjects for the case study. Included in the group were five African students who regarded English as an additional language. They had completed their schooling in the former Department of Education and Training (DET) schools, which are in urban 
townships or rural areas and are still very poorly resourced. The other three students regarded English as their home language. One was an African student who had been to an elite private school one a 'coloured' student from a school formerly reserved for white learners (Model C) and one a white student from a Model $\mathrm{C}$ school. Students were interviewed regularly after each essay so that they could act as 'expert witnesses' (Herrington \& Curtis, 2000: 8) to assist in the analysis of the writing. These interviews also contributed to biographical sketches of the students which provided important contextual data for the study.

The study used the framework Fairclough (1989) developed for analysing the relationship between a linguistic text and wider social processes. In addition to a description of text, Fairclough calls for an interpretation of the social processes that give rise to the production of the text as well as of the social historical conditions within which participants are situated. This forms his three-part model for discourse analysis and it falls under the broader description of Critical Discourse Analysis (CDA). CDA was used to analyse students' interim literacies in order to uncover acquisition processes and to illustrate both the barriers and resources that influence to learning.

\section{Contextualising my data}

Excerpts from my data will serve to illustrate what is meant by interim literacies. Despite different degrees of preparation for university study as well as fluency in English, I would describe all the language and literacy practices of my case study students as interim. All the students were in their first year of university and they were all in the process of acquiring a range of new discourses for the Commerce degree. Some students had been exposed to middle class literacy practices both at home and at school and these coincided quite closely with those taught at university. Therefore, the acquisition of the new academic language was probably a lot less challenging for these students. However, as Bourdieu, Passeron and de Saint Martin point out, 'Academic language is ...no one's mother tongue, not even that of children of the cultivated classes' (1994: 8). I will draw on my data to illustrate and discuss this category of students later, but I want to focus first on the interim nature of the writing of the group of African students from working class and rural backgrounds who spoke English as an additional language (EAL).

For students from different cultural and linguistic backgrounds studying at a university such as this one presents a multitude of difficulties. The teaching staff is still predominantly white and English-speaking. The institutional culture, symbols and patterns of behaviour are unfamiliar and the gaps between familiar yet marginalised discourses and the privileged discourses of the academy are much greater than for students from more middle class backgrounds. In addition, many of the students entering the university are speakers of English as an additional language (EAL) and English is still the medium of instruction at this university. The language of instruction and examination clearly puts EAL students at a serious disadvantage. Recent data shows that in several programmes/degrees at the university, the discrepancy in throughput rate between English first-language and EAL students is currently over $20 \%$ (Toward a Language Plan for UCT, 2003).

Academic writing is ideologically inscribed in terms of the different meanings and identities it privileges and these students find that the academic literacy practices in the Commerce faculty contrast quite strongly with their prior language and literacy practices and they have more difficulty accepting them and taking them on. Gee (1996) and others have pointed out that these students write at a site of struggle between familiar discourses and the dominant discourses of the academy. As they take on the dominant discourses in Commerce, the beliefs and values central to the other discourses with which they are familiar become marginalised. This is not surprising when one considers the strong pressure that students feel to conform to the dominant values of the department, the faculty and the university. They believe that a tertiary education and particularly a degree in Commerce is a way to fulfil their aspirations and escape from poverty.

Students' own values may contradict those of the faculty and the department and they experience confusion and uncertainty as they are inducted into the social practices, values and positions of the institution. Moreover, in a faculty like Commerce, students' own values, discourses and life 
worlds are often hidden by the demands of Commerce curricula, the academic tasks, the assessment systems and the tremendous need students feel to conform and succeed. It is only occasionally in informal discussions that their values and experiences are revealed and one gets glimpses into the kinds of conflicts they are facing.

One such informal classroom discussion was recorded when students were working in an online writing environment and were asked to write a heading and first paragraph for a newspaper article on the gold industry. A common thread that ran through these submissions was that the rising price of gold should lead to wage increases and slow down the retrenchment of mineworkers that was taking place at many of South Africa's gold mines. Retrenchment was seen as a real threat as some of the students' fathers, brothers and uncles were working on the mines. Below are a selection of exerpts from student submissions:

a) GOLD PRICE HAS INCREASE, WHAT ABOUT WAGES

We see that the gold has increased but what about the wages of these people working hard under risk places?

b) HARMONY BRINGS BACK LIFE IN SOUTH AFRICA

The gold price has increased, putting Harmony (mining conglomerate) in a good financial position, the already starving families today have hope that Harmony is going to bring life back to the families.

c) IS PRICE RISE FOR REAL?

Most people in the gold industry are asking the same question because they think the workers who were going to be retrenched are going to continue working.

These excerpts display intriguing examples of intertextuality where students represent their 'interests' (Kress 2000, 2002) by weaving a kind of broader race/class solidarity with the workers on the gold mines together with information gleaned from the internet. They reveal their social historical formation in phrases such as what about the wages of these people working hard under risk places?, while at the same time showing awareness of the requirements of the new context by using economics terms such as PRICE RISE, and financial position. I have quoted these excerpts as examples of interim literacies because they also seem to illustrate an interim stage in the students' lives, reminding us of the conflict of identities these students experience as they grapple with shifts in their own lives in order to prepare themselves for careers as professionals in the world of business. They remind us too that acquisition of academic discourse is not a straightforward, single-track process.

\section{Features of interim literacies \\ Intertextuality: spoken discourses and the oral tradition}

As I indicated earlier, interim literacies are particularly important because of the insights they give us about the connections students are making to previous encounters, other people, ideas, texts, institutions and discourses beyond the confines of the academic institution. Through the exploration of student writing over a period of eight months, I identified a number of characteristics of interim literacies. In the first essay in my study, some students drew strongly on a variety of spoken discourses and genres from a more oral tradition that revealed something of their social and historical roots. This was seen in such features as clause chaining, repetition, rhetorical questioning and the use of first and second person pronouns.

Gee (1996) indicates that when one has not mastered a secondary discourse, one may fall back on one's primary discourse, or one can use another related secondary discourse. I was particularly interested to find that some of the stylistic features in the student writing may be drawn from oral literary language (secondary discourse) rather than everyday spoken discourses (primary discourse). Gough (2000) reminds us that there is a tendency to regard Western essayist discourse as the only secondary discourse, but that in fact all communities have secondary discourses and the secondary discourses of African languages would include those of the oral tradition, such as praise poetry and storytelling. 
Findings from my data and my interviews with students show that some of the practices of Xhosa and Zulu first-language teaching in schools are in fact encouraging the development and usage of African secondary discourses. Two students, Vuyani and Sibongile, Zulu and Xhosa speakers respectively, repeatedly used non-embedded question-and-answer sequences in their first essays and when asked about this, they told me that the way they were using questions and answers in their writing was a discourse style borrowed from the literary genres of their home languages.

Sibongile uses the question-and-answer style to develop a discussion in her text:

What about those poor consumers who don't have any money, are their needs satisfied?

They are poor and they need goods that will cost less and maybe those goods wont be produced 'cause many rich people do not want them. Is this market system pure [fair]? Now the government should look at this and make a plan for those people.

In her interview, Sibongile indicated that she had learned to write 'imibuzo', rhetorical questions, when she was studying Xhosa poetry at school and that the teacher had encouraged them to transfer this discourse style to their own writing:

Vuyani, another student, said he had learned the question-and-answer technique from reading Zulu stories and transferred it to his own writing,

'When we're writing an essay in Zulu, to make it more interesting you ask a question and then you answer it... it is the way to emphasise'

Below are some examples of the way in which Vuyani has used question forms in his economics essay:

The people or labour were owned by state. How? There was this document which they called it pass.

Why does SA prefer the mixed economy? Because more money is being produced...

The question which is remaining now is that 'is SA economy undergone a transition since 1990 to a market oriented economy?' I would say yes. Why. First of all...

The question-and-answer style would typically look like the three parallel couplets below, which have been taken from Zwide's praise poem (Cope, 1965: 62):

Ezindleleni ufana nayiphi na?

Ufana nevudlayo;

Emithini lapha ufana nayiphi na?

Ufana nomnyamathi;

Ezinyokeni lapha ufana nayiphi na?

Unfana nenyandezulu.

Amongst the roads which one does he resemble?

$\mathrm{He}$ is like the one which cuts straight across;

Amongst the trees which one does he resemble?

$\mathrm{He}$ is like the hardy essenwood tree;

Amongst the snakes which one does he resemble?

$\mathrm{He}$ is like the large green one which represents the ancestors.

The examples from the students' writing illustrate the way the students' interests are reflected in their writing and how, in the process of transferring the traditional rhetorical form, they attempt to transform it so that it is appropriate to the new academic discourse. Bakhtin (1981: 291) describes this intermingling of discourses as 'hybridity' and he says that all language is hybrid, 'heteroglot from top to bottom'. However, what makes these extracts so interesting is that the intermingling of other discourses is so overt that it is possible to trace the different discourses and to identify them. As Kress (2000: 155) says, 'our interests in communication never really match the existent semiotic resources, but we choose the most apt forms to represent our meanings and as there is never a perfect fit, the resources are always transformed'. 
In the final essay of the year, there was evidence of prior discourses being reworked and rearticulated so that they blended more appropriately in the new context. For instance, in the extract below Vuyani has refined his use of the rhetorical question (umbuzo buciko) so that it looks acceptable as the introduction to his monopoly essay:

How does SAB choose profit maximising output? What we know is that most of the

monopolist firm produce where marginal revenue is equal to marginal cost, this is profit

maximising rule.

The marker compliments him on his effective use of the question-and-answer form with a comment in the margin saying, Nice opening question/topic sentence. The reader knows what the paragraph is about. Vuyani continues to use rhetorical questions quite appropriately throughout the essay, showing that he is importing the older literary form and then re-articulating and contextualising it in his academic writing as he moves through his first year of study. His prior discourses have scaffolded acquisition of the new. For instance, in this final essay Vuyani's sentence structure has improved and he seems to have learned effective ways of using the rhetorical device. Interestingly, he uses the first person and the active voice to convey his message clearly and directly, whereas more traditional economics texts tend to obscure the message, because they use the passive voice and intransitive verb forms to remove the agent.

The rhetorical form is a device used in oral praise poetry to engage the audience and hold their attention. Other traces of the more socially involved narrative and spoken discourses (Chafe, 1982) could be found in the way students used the first and second person pronouns to appeal to their audience, share personal experience and establish authorial presence, as in the examples below:

It's like we are still living in the Apartheid time where if you don't have money then your needs and wants wont be satisfy. South Africa is a country in transition things are getting better. Let us give the country a chance and hope the rate of crime will go down.

(Sibongile)

There are a lot of enterprises which we believe black people should own them. (Vuyani)

My data indicates that once again students were drawing on prior discourses to own their ideas and interact with their readers. But the use of the first person is a practice that economic educators actively discourage because they adhere to traditional essayist literacy practices, believing that scholarly writing is an impersonal, objective exploration of ideas in which the author is disguised.

\section{Intertextuality: drawing on associations to build meaning}

Woven into the stages in the development of interim literacies is the growth in conceptual understanding. An intertextual analysis reveals the associations that students draw on to assist them in building new concepts. My research shows that these were linked to social and cultural contexts. Examples from the first essay on the post-apartheid transition in South Africa from a more command orientated economy to a market economy showed how the students' different life experiences of the apartheid years shaped their understanding of the distorted economic system in place under apartheid.

In the discipline of economics, writers' own experiences are not valued and there was evidence that drawing on personal situated meanings can sometimes serve to confuse, rather than to contribute to economic understanding. However, there are other illustrations in the data that indicate that students' situated meanings are important because they can provide them with a framework for learning new concepts. There were instances where students drew on mental models they had created to access new concepts. Nomsa provides an interesting example when she claims that consumers are the boss of the market, a phrase which tutors and markers would recognise as useful in learning terms but too informal to be appropriate in an essay. Nomsa's phrase probably originated in a tutor's attempt to explain a new concept. The term 'consumer sovereignty' in the economics of the market system means that consumers have sovereignty because they have the power to determine the types and quantities of goods and services which will be produced. This concept would be somewhat unfamiliar to the students, but in a tutorial that I 
attended the tutor simplified it for them by referring to consumers as 'sovereign' or 'king'. In her sentence, Nomsa has revealed her 'on-the-spot' image of the consumer as 'boss', an image which she has assembled to help her understand this concept. Thus, in a sense the tutor has created a mental model to assist the students. As I have indicated, this drawing on situated meanings and mental models is an important step in the learning process.

\section{Intertextuality: 'Borrowing' and mimicking the new discourse}

A further feature of interim literacies is the close mimicking or open 'plagiarism' of the discourse of the textbook or the lecturer (Paxton, 2004). This was again most vividly illustrated by Vuyani in his second essay where he regurgitated large chunks of text directly from the internet (Paxton, 2003a). These extended borrowings from the original sources would be described by the university authorities as 'plagiarism'. However, I believe that Vuyani's selection of these pieces from the Internet arises out of his assessment of the context for which he is writing and quite an astute sense of the ways in which power works in that context. He had failed his first essay where his own voice, mingling with a range of prior discourses, emerged quite strongly (see excerpts above) and he recognised the values placed on the powerful economic discourses that he finds on the web. However, the new discourse is so alien, so 'indissolubly fused' (Bakhtin, 1981: 343) with the authority of others that he cannot yet transform it to make it his own and therefore he reproduces it.

\section{Avoiding terminology from the new discourse}

Interim literacies may also be characterised by deliberate avoidance of the new terminology. This was evident in the writing of the final economics essay on monopolies. This essay was more technical and analytical and the use of nominal phrases such as 'barriers to entry' and 'economies of scale' should allow the students to discuss this aspect of monopoly firms quite neatly and concisely. But instead they avoid using the terms altogether and use circuitous and long-winded explanations which make their writing confusing. The excerpt below from Thabo's essay illustrates his avoidance of these terms:

The other things that SAB do is to block the entries of other firms or competitors indirectly.

By indirectly I mean by its lowering its prices it is becoming difficult for other big breweries who wishes to operate in South Africa, because they will be forced to lower their prices in order to compete in the industry. By lowering their prices they won't realise maximum profit as SAB does because they won't use the same cost of production as SAB uses.

The passage indicates that Thabo does understand the concept of economies of scale but he tries to express it without using the appropriate terms, with the result that his exposition is limited and confused. The lecturer comments that the underlined section needs to be explained further and that the student needs to use the terms 'barriers to entry' and 'economies of scale'.

It seems likely that at this interim stage, the EAL students deliberately avoid the use of these terms because, despite strong social pressures to use appropriate economic terms, the terms seem alien to them. This might be a necessary stage in the interim literacies between borrowing misunderstood terms and learning to use those terms appropriately. At this stage the students don't fully understand the terms and don't feel comfortable using them; they have not yet assimilated the discourse. As Bakhtin (1981: 294) states:

...not all words for just anyone submit equally easily to this appropriation, to this seizure and transformation into private property: many words stubbornly resist, others remain alien, sound foreign in the mouth of the one who has appropriated them.

\section{Lack of coherence}

A further feature of interim literacies that was displayed in all the student writing was a lack of coherence. Coherence is a difficult concept to pin down, but for my purposes, I regard a passage of writing as coherent if there has been some development of argument around a main idea so that all subsequent propositions are relevant and logically sequential. This entails using cohesive 
markers and/or semantic relations to signpost and link ideas in a logical way. Philip, a student from a former Model $\mathrm{C}$ school in one of the wealthier suburbs of Cape Town who had been exposed to middle class literacy practices at home and at school, struggled to articulate his notion of academic argument. He introduced his essay by indicating that he was going to present an argument but when I asked what he meant by the word argument he said, When you have an argument with someone, there's obviously a disagreement and one person's trying to oppose the person who's proposing it. His essay showed that he clearly did not understand an academic argument as building a case around something by bringing evidence to support the claims made. All the students experienced difficulties in structuring their writing in a logical and coherent way and in their interviews they explained that essay-writing practices at school had encouraged them to get 'the facts' down as quickly as possible without paying attention to coherence or logical development of argument. This is the 'thirty marks for thirty facts' phenomenon to which Kapp refers (2001: 243).

\section{Discussion}

It has been important to illustrate and explain in some detail the findings that have led me to attach the label of interim literacies to my students' writing to ensure that the metaphor may not be misconstrued. Lakoff and Johnson (1980) point out that metaphors structure how we perceive and think and new metaphors create a new reality. While the new metaphor of interim literacies allows me to highlight certain aspects of my analysis of student writing, it can very quickly acquire the status of a truth and therefore it needs to be considered quite critically. I need to be asking what the perceptions and inferences are that might follow from this metaphor and what actions may be sanctioned by it. For instance, metaphors such as this one can be used to label students as 'interim', marking them and never allowing them to move beyond this stage. Interim literacies, used in this sense, might imply fossilisation of literacies and literacy practices. Or the term 'interim' might be applied to these students to signify that they are only in the economics department for an interim period.

Because of the ways in which this new metaphor may be misconstrued, I want to be clear about what it implies and what sort of writing might be categorised as 'interim'. Firstly, whose writing can be described as interim? From my data it is clear that most students in their first year of study have difficulty acquiring the complex discourses of academia. The writing of students from more privileged middle class homes displayed quite a few of the features I have described above. However, first language speakers of English from more privileged homes acquire the new discourses quite quickly. It is the EAL students from different discourses and traditions who face real challenges in gaining access to these academic discourses Therefore, in some senses, it is true to say that at a foundational level, where writers are gaining access to entirely new discourses and genres, all language and literacy practices/usages could be considered 'interim'. This view is supported by colleagues in the sciences and engineering who have become interested in education and had to acquire the discourses of the social sciences to complete postgraduate degrees in higher education. They have commented on the struggles they experienced and agreed that, in the initial stages, 'interim literacies' is an appropriate descriptor for their writing too.

My data conveys the sense that interim literacies are about meaning-making and in a few of the excerpts one is able to actually see meaning in the making. Meaning-making is a dynamic resource, constantly being adapted and transformed by its users. Therefore, the term interim must imply fluidity, a sense of movement and change. At this point it seems useful to summarise the features of interim literacies that I have identified and to present these features in developmental terms. In this way we can work towards an understanding of what interim literacies are and what they are not. In my analysis of first year student writing I have particularly highlighted the hybridity, the traces of prior discourses and discourse strategies as very distinctive features of interim literacies, particularly evident in the first academic essay. This hybridity often provides us with insights into how past discourses and discourse models assist in concept formation. I noted that at 
first this hybridity might be very obvious, but later in the year there were signs that the prior discourse strategies had been rearticulated so that they seemed more appropriate for the new context. A second feature of the interim literacies would be the ways in which students mimic the new discourses by reproducing chunks of them in their essays. Thirdly, some students deliberately avoid the use of new terminology. This seems to stem from a resistance to the new terms and I noted that this might be a necessary stage for some between borrowing misunderstood terms and learning to use the new terms appropriately. Lack of coherence is a further feature of interim literacies identified in my data.

There are probably many other features that I have not identified, but what seems clear is that interim literacies are not simply in need of surface editing. It is not a lack of correct grammar that allows us to classify a piece of writing as interim. But rather, my analysis illustrates that the term interim is centrally, but not only, about hybrid, polyvocal texts. As I have indicated, I consider Bakhtin's (1981) notion of interlinked texts and voices (ideological perspectives) as crucial for understanding the way students weave other voices into their texts in order to make meaning and to develop a voice of their own.

Bakhtin says that writers play a unique role in shaping their own words and texts:

The importance of struggling with another's discourse, its influence in the history of an individual's coming to ideological consciousness, is enormous. One's own discourse and one's own voice, although born of another or dynamically stimulated by another, will sooner or later begin to liberate themselves from the authority of the other's discourse. This process is made more complex by the fact that a variety of alien voices enter into the struggle for influence within an individual's consciousness (just as they struggle with another in surrounding social reality) (Bakhtin, 1981: 348).

From Bakhtin's metaphors we get a sense of how the writer struggles to develop ownership of the hybrid discourses that enter his/her consciousness. S/he needs to 'populate them with his (sic) own intentions', 'appropriate' them and 'adapt' them (1981: 294). Thus, for Bakhtin, the self is discursively mobilised as one's discourses, experiences and practices are integrated. As the students construct their texts, they construct themselves.

For a number of reasons I believe that, despite the danger of misconstrual, interim literacies is a very useful notion and an analysis and understanding of it can contribute to our teaching and to transformation. Firstly, interim literacies provide us with insights into who our students are. If interim literacies are about heteroglossic voices and the shaping of identities, we might need to ask some difficult questions about what kinds of identities our institutions of higher learning are shaping. Is there room for valuing and acknowledging the hybrid discourses I have illustrated or will our students simply have to be socialised into the dominant models of meaning construction and representation in our universities? Certainly there seems to be very little flexibility in economics curricula to accept different ways of seeing the world. Our students simply have to learn to leap the hurdles, acquire the discourses and turn themselves into carbon-copied economists. Few students from working class backgrounds progress to a major in economics at my university and even fewer are admitted to postgraduate studies in economics, which seems to indicate that the 'interimness' of their literacy practices may prevent them from proceeding further with their studies. This means that the dominant models are still privileging students from select cultural and language groups and excluding the others. Consequently, the dominant ideologies keep on reproducing themselves. Can we not begin to imagine ways in which these different identities and literacy practices can make a contribution to the discourses and institutions of higher education?

Secondly, the hybridity in these student texts is so overt that it can provide us with clues as to future developments and changes in literacies and discourses. Through an analysis of interim literacies such as these, we begin to question the dominant role of essayist literacy practices. We teach at a time when literacy practices and discourses are in flux and changes in the social, economic, communicative and technological world will, as Kress (2004) notes, shape the futures of literacy. Kress's new theory of representation may assist us in answering some of these questions. 
The world beyond the university boundaries is a world of changing reading and writing practices, multimodal texts, the Internet, SMS and email. As these new literary practices infiltrate our universities it is becoming more and more difficult to gate-keep, to adhere to conventional practices, rules and regulations and to decide who is the author and who originally produced the text. Surely this calls for more openness and creativity in the practices and discourses we are prepared to accept? Is it possible then that students' diverse language and literacy practices can in fact become recognised as legitimate ways of meaning-making in academia?

Thirdly, probing the rich intertextuality of these texts allows us, as educators, to understand more about learning and meaning-making processes. Understanding students' values and experiences may provide us with new insights and guidelines for shaping our future curricula to cater to the needs of students from diverse backgrounds. It enables us to identify weaknesses in our teaching and our curricula and to recognise where our teaching may or may not have made sense and where traditional educational methodologies may need to be changed. In this way, the institution begins to benefit from the contributions of students from diverse backgrounds.

South African universities, faced with shrinking resources and increasing student numbers, do not seem particularly effective at moving students from different cultural and linguistic backgrounds beyond the interim stage and graduating them. Teaching staff in universities have been very reluctant to recognise that the acquisition of new academic discourses requires mediation; interim literacies would only fossilise in situations where students are not being assisted in the acquisition of academic literacies. Teaching to support meaning-making needs to be an ongoing process. We need to take a very critical look at our teaching methodologies and ask ourselves whether appropriate scaffolds are in place for taking students beyond the interim stage.

\section{Conclusion}

I want to conclude by pointing to some of the ways in which students may be assisted in moving beyond the 'interim stage'. The kind of model I have used in my research allows for negotiation of meaning. Theresa Lillis (2001) refers to this as the 'talkback model' where the researcher draws on the students as informants to provide him/her with an understanding of how they are making meaning. I believe this kind of collaborative talk could be used between writers and tutors to facilitate greater control over meaning-making. In the process, students not only learn from the tutor but the tutor might also discover more about the associations students are making, which can provide him/her with new ideas about how to get the message across. This model also has the potential to push the boundaries of what counts as acceptable meaning in the academy and to move us away from traditional conventions and ways of knowing that serve to gate-keep rather than to facilitate access.

I want to draw on a few examples from our own teaching to illustrate the impact this type of research can have. For instance, ECO100A which was the course site for this research project has changed because of the findings of the project. Because the data indicated that students were not as familiar with the history of the apartheid economy as had been assumed and that students' different life experiences had shaped what they knew of this period, the economics lecturers now include a section on the history of the South African economy during apartheid. This also forms a section in the new textbook written by these lecturers and published recently (Muradzikwa, Smith \& de Villiers, 2004). Perhaps even more interesting is the way these new textbook writers have moved from the more traditional scientific language used in economics texts to make the language of the new book much more accessible. They have increased accessibility by using fewer abstractions, passive voice constructions and long nominal groups than the imported American textbooks use.

In our teaching in the Language and Communications module, we have tried to make connections to some of the research findings and to make the metalanguage more visible and more explicit. For instance, we talk about rhetorical questions and contrast the way they might be used in praise poems to what would be regarded as acceptable use in economics texts. We teach students how to use modal verbs in the application of the economic model to real world contexts. This idea 
arose because I found that students were having difficulty applying the simplified economic model to the real world. In explaining the model, one uses simple present tense forms of the verb whereas the real-world situations are far more nuanced and more tentative and require quite sophisticated use of modal verbs. Students benefit by being explicitly taught ways of using modal verbs appropriately in real world contexts.

\section{Notes}

${ }^{1}$ This term was used by Associate Professor Alison Lee (University of Technology Sydney) in feedback on an early draft of the article, 'Developing Academic Literacy in Economics in a South African University' (Paxton, 2003a).

\section{References}

Bakhtin MM. 1981. The Dialogic Imagination. Austin: University of Texas Press.

Bourdieu P, Passeron JC \& de Saint Martin M. 1994. Academic Discourse. Cambridge: Polity Press.

Chafe W. 1982. Integration and involvement in speaking and writing, and or oral literature. In Tonnen D (ed.). Spoken and Written Language: exploring orality and literacy. Norwood: Ablex, pp 35-53.

Cope AT. 1965. Izibongo: Zulu praise poems. London: OLAL.

Fairclough N. 1989. Language and power. London: Longman.

Gee J. 1996. Social Linguistics and Literacies: Ideology in Discourses (2 nd edn). London: Routledge/Falmer.

Gough D. 2000. Discourse and students' experience of higher education. In: Leibowitz B \& Mohamed Y (eds), Routes to Writing in Southern Africa. Cape Town: Silk Road, pp 43-58.

Herrington A \& Curtis M. 2000. Persons in Process. Urbana, Illinois: National Council of Teachers of English.

Ivanic R. 1997. Writing and Identity: The discoursal construction of identity in academic writing. Amsterdam: John Benjamins.

Kapp R. 2001. The Politics of English: A study of classroom discourses in a township school. Unpublished Doctoral Dissertation, University of Cape Town.

Kress G. 2000. Design and transformation: new theories of meaning. In: Cope B and Kalantzis M (eds), Multiliteracies: literacy learning and the design of social futures. London and New York: Routledge, pp 153-161.

Kress G. 2002. From Saussure to Critical Sociolinguistics: The Turn Towards a Social View of Language. In: Wetherell M, Taylor S and Yates S (eds), Discourse Theory and Practice. London: Sage, pp 29-38.

Kress G. 2004. Literacy in the New Media Age. New York: Routledge.

Lakoff G \& Johnson M. 1980. Metaphors we live by. Chicago: University of Chicago Press.

Lillis T. 2001. Student Writing: Access, Regulation and Desire. New York: Routledge.

Muradzikwa S, Smith L \& de Villiers P. 2004. Economics. Oxford: Oxford University Press.

Paxton M. 2003a. Developing academic literacy in economics in a South African university. Literacy and Numeracy Studies 12(2): 1-14.

Paxton M. 2004. Intertextuality in student writing: the intersection of the academic curriculum and student voices in first-year economics assignments. Unpublished Doctoral Dissertation, University of Cape Town.

Street BV. 1995. Social Literacies. London: Longman.

University of Cape Town. 2003. Toward a language plan for UCT 2005-2010. University document of Senate. Available at: http://www.ched.uct.ac.za/adp/ldg/senate_multilingualism.pdf [accessed 22 July 2004]. 